\title{
DO INDIVIDUAL FACTORS MATTER? EXAMINING AUDITOR JUDGEMENT BIAS AND PUBLIC ACCOUNTING FIRM SIZE
}

\author{
Caesar Marga Putri* \\ Faculty of Economics and Business, Universitas Muhammadiyah Yogyakarta, Indonesia \\ Asti Putri Pratiwi \\ Faculty of Economics and Business, Universitas Muhammadiyah Yogyakarta, Indonesia
}

\begin{abstract}
Auditor personality is a topic of interest within the accounting field due to the scarcity of research on accountant personalities in Indonesia. This research aimed to examine the moderating effect of public accounting firm size, personality traits and locus of control on the correlation between role conflict and auditor judgement bias. The sample comprises auditors who work at public accounting firms in Java province and the study uses regression analysis as its method of analysis. The result shows that only internal locus of control has a significant moderating effect on the relationship between role conflict and auditor judgement bias. This indicates that auditor personality and public accounting firm size do not affect auditors' professionalism in making judgements.
\end{abstract}

Keywords: auditor judgment, role conflict, personality, locus of control

Received: 17 May 2020

Accepted: 31 July 2021

https://doi.org/10.33736/ijbs.4297.2021

\section{INTRODUCTION}

According to CNBC Indonesia, until early August 2019, a problem ensnared four well-known public accounting firms in Indonesia, two of which are affiliated with the Big Four. The four public accounting firms in question are KAP Purwanto, Sungkoro, and Surja, which are affiliated with Ernst and Young, KAP Tanubrata, Sutanto, Fahmi, Bambang \& Rekan, and KAP Amir Abadi Jusuf, Aryanto, Mawar \& Rekan, and KAP Satrio, Bing, Eny \& Rekan that is affiliated with Deloitte (Ayuningtyas, 2019). This situation indicates that in the judgement process, auditors can make mistakes that may affect public trust.

Professionalism is an important element during audit fieldwork. An auditor has two essential roles, as a member of the organisation (public accounting firm) and a member of the profession. As a result, an auditor can experience conflict between the values of the accounting firm where they work and their professional values as an auditor. In contrast, as an individual, an auditor's behaviour can influence their professional judgement when working in a conflict situation (Iswari

\footnotetext{
* Corresponding author: Faculty of Economics and Business, Universitas Muhammadiyah Yogyakarta. Jalan Brawijaya, Tamantirto,

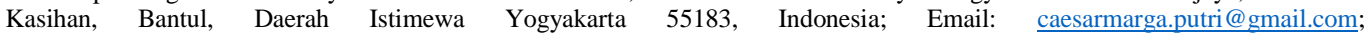
caesar.margaputri@umy.ac.id
} 
\& Kusuma, 2013). Fanani, Hanif and Subroto (2008) explained that auditor performance can be influenced by the working conditions they face and that this may affect public trust in the auditing of financial statements undertaken by public accountants, who act as independent parties. Auditors' performance is a result of their work and is something they earn when performing their obligation based on the responsibility assigned to them. As such, it is one of the tools used to determine whether a job is good or not (Fanani et al., 2008). A judgement made by an auditor can be considered good if their performance is also good.

Auditor judgement consists of any assessment or decision that affects the process or the result of an auditor's performance when auditing financial statements (Wedemeyer, 2010). In providing their responses to and evaluations of information, an auditor has perceptions that can be influenced by several factors, including their level of knowledge, the behaviour of the auditor in obtaining and evaluating information and the complexity of the task when conducting an examination (Jamilah, et al., 2007). Role conflict arises when a situation forces someone to do another job concurrently, where the second job is different from and incompatible with the first. This can create stress which in turn can adversely affect a person's ability to achieve their goals (Yustrianthe, 2008). Therefore, the role conflict experienced by auditors can influence them when forming judgements on a financial report.

Sawan and Alsaqqa (2013) explained that the Big Four have enhanced capabilities, effectiveness and independence compared to the non-Big Four. However, this opinion is not in line with Iswari and Hardini (2017), who asserted that auditors who work in one of the Big Four public accounting firms and who are exposed to organisational-professional conflicts in their work environment are more likely to make biased judgements than auditors who work in a non-Big Four public accounting firm. Larger public accounting firms are also characterised by greater work stress, which will also affect the auditors' judgement. Therefore, the size of the public accounting firm may moderate the relationship between role conflict and auditor judgement bias.

Personality traits form the basis of someone's considerations, feelings and behaviours that are the foundation of their individual personality (Barrick \& Mount, 2005). Ramdhani (2007) explained that an individual's personality can influence their behaviour, cognition and motivation. Meanwhile, Iswari and Kusuma (2013) found that personality type can strengthen the influence of organisational-professional conflict on professional judgement. Farhadi et al. (2012) reported that conscientiousness negatively affects dysfunctional behaviour. Therefore, differences in individuals' personality traits will result in them responding differently to a similar problem.

Another factor that determines an individual's motivation is the locus of control. Differences in the locus of control will also affect the different motivations and performances of individuals (Kartika \& Wijayanti, 2007). Evanauli and Nazaruddin (2016) stated that someone's locus of control reflects the way in which they perceive the success or failure that occurs in their lives, notably in terms of whether it results from their own deeds or other factors influence it. Srimindarti et al. (2015), Fatimah (2012), and Harini et al. (2010) found that the locus of control can impact on dysfunctional audit behaviour. Meanwhile, Iswari and Kusuma (2013) found that locus of control did not have a significant effect on the relationship between professional-organisational conflict and professional judgement. Different auditors experiencing the same role conflict may respond to it differently. This occurs because every auditor has a different personality and this affects the 
different ways in which they resolve conflict. Therefore, locus of control and personality traits can influence an auditor's judgement when in a role conflict situation.

This research aims to examine whether role conflict has an influence on auditor judgement and test the influence of three moderating variables, namely public accounting firm size, personality traits and locus of control. This research is motivated by the relative scarcity in Indonesia of studies examining the influence of auditors' personality on the quality of judgement, notably of studies using the Big Five personality traits as a measure. This research differs with regard to its use of the Big Five personality traits to divide personality traits and its use of the locus of control as a moderating and not an independent variable.

\section{LITERATURE REVIEW}

\subsection{Cognitive Dissonance Theory}

In 1957, Leon Festinger introduced cognitive dissonance theory. Dissonance indicates the presence of inconsistency, so that cognitive dissonance can be interpreted as an adverse situation with respect to someone's psychology. It can arise due to a conflict between two cognitions or a conflict between attitudes and behaviour within the human (Noviyanti, 2008). Srirejeki (2016) explained that in dealing with a similar situation, two people will have unequal opportunities when in dissonant conditions. Therefore, this theory can be used to assess an auditor's behaviour in dealing with conflict situations related to personality traits, locus of control and public accounting firm size.

\subsection{Relationship of Role Conflict and Auditor Judgment Bias}

An auditor experiencing conflict between the organisation's values and the professional values will tend to become involved in deviant behaviour while performing their duties as an auditor. This deviant behaviour can affect the auditor's professional judgement, which consequently influences his judgement to deviate from the applied standard (Iswari \& Kusuma, 2013). Agustina (2009) and Fanani et al. (2008) found that role conflict negatively affects the performance of auditors. This research is supported by Afifah et al. (2015) and Fisher (2001), who stated that role conflict could degrade the auditor's performance. Fisher (2001) and Sorensen and Sorensen (1974) found a negative relationship between role conflict and auditor job satisfaction. In addition, role conflict will increase the level of work pressure felt by an auditor (Senatra, 1980).

Role conflict that occurs in an audit environment will only have a negative impact on the performance of the auditors. It will naturally influence the quality of their judgement, which will be reduced. Therefore, the greater the conflict experienced by an auditor, the more biased the resulting judgement. Based on the explanation above, the following hypothesis can be derived:

\section{$\boldsymbol{H}_{1:}$ Role conflict positively affects auditor judgement bias.}




\subsection{Influence of Public Accounting Firm Size on the Relationship between Role Conflict and Auditor Judgement Bias}

Public accounting firm size can be classified into two types: a public accounting firm that is affiliated with the Big Four, and a non-affiliated or non-Big Four accounting firm (Arens, et al. 2012). The larger the public accounting firm, the greater the work stress, which will affect the resulting judgement. This is supported by Iswari and Hardini (2017), who found that public accounting firm size can moderate the relationship between organisation-professional conflict and auditor judgement.

Iswari and Hardini (2017) found that auditors who work in a Big Four public accounting firm and deal with organisational-professional conflict are more likely to make biased judgements compared to auditors who work in a non-Big Four public accounting firm. This can happen because auditors who work in the Big Four deal with more complicated issues and must show greater consideration. In addition, the Big Four have higher audit standards and greater work pressures, leading to greater work stress. Therefore, the bigger the public accounting firm, the greater the conflicts encountered and the greater the potential for biased judgement. Based on the explanation above, the following hypothesis is derived:

$\boldsymbol{H}_{2}$ : Auditors who work in a Big Four public accounting firm are more likely to make biased judgements than auditors who work in a non-Big Four public accounting firm when dealing with role conflict.

\subsection{Influence of Personality Traits on the Relationship between Role Conflict and Auditor Judgement Bias}

Openness to experience is one of the personality traits in individuals who are described as innovative, have a strong imagination, and are insightful and open to new things (Goldberg, 1990). Denissen and Penke (2008) and Rustiarini (2013b) found that this personality trait weakens the positive relationship between job stress and dysfunctional audit behaviour. Denissen and Penke (2008) found that individuals with this personality trait can solve problems in a short time, with only limited information, as well as large uncertainties. Given their character, auditors with this personality trait will be able to overcome the conflict they experience between organisational and professional values and thus reduce the possibility of making biased judgements. Based on the explanation above, the following hypothesis is derived:

\section{$\boldsymbol{H}_{3 a:}$ Openness to experience weakens the relationship between role conflict and auditor judgement bias.}

Someone with a conscientious personality has the characteristics of being trustworthy, enterprising, organised, responsible and competent (Goldberg, 1990). Bowling and Eschleman (2010) and Farhadi et al. (2012) asserted that conscientiousness negatively affects dysfunctional behaviour. Rustiarini (2013b) found that this personality trait weakens the relationship between job stress and dysfunctional behaviour. Auditors with this personality trait can reduce the possibility of making biased judgements as they have a credible and responsible character. Therefore, even when in a role conflict situation, an auditor with this personality trait will still try to be responsible with his 
judgement so that he does not produce biased judgements. Based on the explanation above, the following hypothesis is derived.

\section{$\boldsymbol{H}_{3 b}:$ Conscientiousness weakens the relationship between role conflict and auditor judgement bias.}

Someone with extraversion personality traits tends to be talkative, passionate, have positive emotions, be energetic, like a challenge, get along easily and also quickly adjust to their surrounding environment (Judge et al., 2002). Judge et al. (2002) found that extraversion has a positive effect on job satisfaction. Rustiarini (2013a) found that this personality trait positively affects auditor performance. Auditors with this personality trait will perceive the conflicts that occur in their work as a challenge they have to resolve in order to improve their quality. Their positive emotions will help them to reduce the number of biased judgements that can be generated when in a conflict situation. Based on the explanation above, the following hypothesis is derived:

\section{$\boldsymbol{H}_{3 c}$ : Extraversion weakens the relationship between role conflict and auditor judgement bias.}

Agreeableness in an individual's personality includes elements such as a great sense of forgiveness and tolerance, being likeable, caring and finding it easy to work with other people (Goldberg, 1990). Graziano and Tobin (2002) explained that agreeableness is synonymous with individuals who want to create good relationships and who seek to minimise interpersonal conflict, maintain existing cooperation and negotiate to end a conflict. Barrick and Mount (1991) and Rustiarini (2013a) found that this type of personality negatively affects auditor performance. Rustiarini (2013b), meanwhile, found that this personality can strengthen the relationship between job stress and dysfunctional behaviour. Auditors with this personality may produce a biased judgement when in a situation that creates role conflict within them. This is because auditors with agreeable personalities tend to tolerate their colleagues in order to maintain cooperation and avoid any conflicts that may arise. Based on this explanation, the following hypothesis is derived:

\section{$\boldsymbol{H}_{3 d}$ : Agreeableness strengthens the relationship between role conflict and auditor judgement bias.}

A person with the neuroticism personality trait can be described as often feeling worried, tense, stressed, gloomy, sad, depressed and anxious (Rustiarini, 2013b). Judge et al. (2002) found that this personality trait has a negative effect on job satisfaction. In Rustiarini (2013a), it was found to negatively affect the performance of auditors. Auditors with this personality trait will make biased judgements when faced with a conflict-filled situation. This can happen because auditors with the neuroticism trait feel tense and anxious. The existence of role conflict can make them feel depressed and lead to the emergence of negative thoughts that can reduce the quality of the judgements they make. Based on this explanation, the following hypothesis is derived:

\section{$\mathrm{H}_{3 e}:$ Neuroticism strengthens the relationship between role conflict and auditor judgement bias.}




\subsection{Influence of the Locus of Control on the Relationship between Role Conflict and Auditor Judgement Bias}

A person with a high internal locus of control will assume that everything that happens in their life does so as a result of their own actions or deeds. Rustiarini (2013b) stated that individuals with a high internal locus of control tend to like jobs that challenge them so that when under pressure from their superiors, they do not experience work stress. This also motivates auditors to improve their performance.

Rustiarini (2013b) found that auditors with an internal locus of control are more able to control their behaviour so they can avoid dysfunctional behaviour. This finding is supported by Srimindarti et al. (2015), Fatimah (2012), and Kartika and Wijayanti (2007), who stated that the higher an auditor's internal locus of control, the lower their tendency to perform dysfunctional behaviour. People who have an internal locus of control tend to overcome the discomfort they feel when in situations that cause role conflict. Therefore, they will tend to reduce the biased judgements that they make. Based on the explanation above, the following hypothesis can be derived:

\section{$\boldsymbol{H}_{4 a}$ : Internal locus of control weakens the relationship between role conflict and auditor judgement bias.}

Individuals with a high external locus of control tend to assume that every outcome in their life is solely the result of fate and luck. Auditors who have a high external locus of control tend to prefer their work to be stable, organised, uncomplicated and for their superiors to exert full control (Rustiarini, 2013b).

Rustiarini (2013b) found that external locus of control can strengthen the relationship between job stress and dysfunctional audit behaviour. Harini et al. (2010) explained that auditors with an external locus of control will have a high tendency to accept any deviant behaviour that occurs within auditing. This result was supported by Evanauli and Nazaruddin (2016), Srimindarti et al. (2015), and Fatimah (2012), who found that external locus of control has a positive effect on dysfunctional audit behaviour. Auditors with an external locus of control will feel uncomfortable in situations of role conflict as the conflict will render their work irregular and more complicated. Therefore, role conflict tends to result in them making biased judgements. Based on the explanation above, the following hypothesis is derived:

$\boldsymbol{H}_{4 b}$ : External locus of control strengthens the relationship between role conflict and auditor judgement bias. 
Figure 1: Research Model

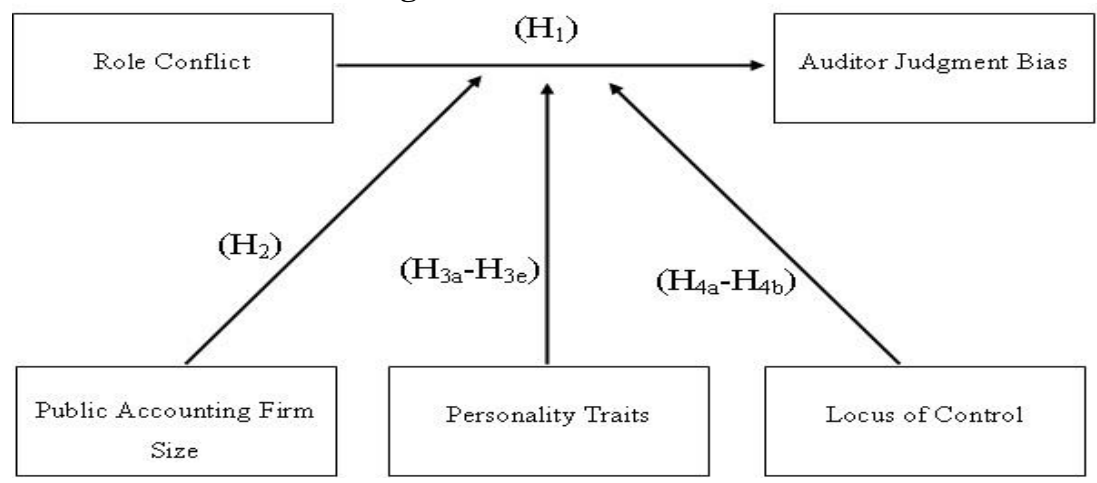

3. METHODOLOGY

\subsection{Research Subject}

This research was conducted at public accounting firms located in Java because, according to Suhariyanto in Kompas.com, this region makes the greatest contribution to the Indonesian economy, at 59.11\% (Fauzia, 2019). The population of this study comprises auditors who work in public accounting firms located in the above-mentioned area while the research sample consists of auditors that meet a set of predetermined criteria.

\subsection{Sampling Technique}

Purposive sampling was used in this research, based on which the sample is determined by setting certain criteria that those selected for inclusion must meet (Sugiyono, 2014). The criteria used to determine the sample in this study comprised auditors who fully completed the questionnaire and who were not an outlier in the data testing. An outlier was determined using the $\mathrm{z}$-score, with a zscore $>2.5$ or $<-2.5$ deemed to indicate an outlier.

\subsection{Operational Definition of Variables}

\section{Auditor Judgment Bias}

Auditor judgement bias is a deviation that occurs in the decision-making process undertaken by an auditor that affects the results of the audit on the financial statements. This variable is measured using the instruments developed by Jamilah et al. (2007), which for this variable involves a 1-5 Likert scale.

\section{Role Conflict}

Role conflict is conflict that arises because the bureaucratic control mechanisms that exist in an organisation are not in accordance with norms, rules, ethics and professionalism (Afifah et al., 2015). This variable is measured using the instruments developed by Fanani et al. (2008), which for this variable comprises seven item statements and measurement using a 1-5 Likert scale. 


\section{Public Accounting Firm Size}

Public accounting firm size, as the moderating variable in this study, is measured using dummy variables. The value 0 is assigned to a non-Big Four public accounting firm and the value 1 is assigned to a public accounting firm that is affiliated with the Big Four.

\section{Personality Traits}

Personality traits act as the essential foundation of an individual's personality, which serves as the basis of that person in terms of their ways of thinking, behaving and expressing their emotions (Barrick \& Mount, 2005). This variable was measured based on dividing the Big Five personality traits into the following five dimensions: openness to experience, conscientiousness, extraversion, agreeableness and neuroticism. The questionnaire used in this study was adapted from McCrae and Costa (1987). The questionnaire consisted of 44 statement items with the following measurement information for each dimension:

a. Openness to experience consists of ten statement items contained in numbers (5), (10), (15), (20), (25), (30), (35), (40), (41) and (44).

b. Conscientiousness has nine item statements contained in numbers (3), (8), (13), (18), (23), (28), (33), (38) and (43).

c. Extraversion comprises eight statement items contained in numbers (1), (6), (11), (16), (21), (26), (31) and (36).

d. Agreeableness consists of nine statement items contained in numbers (2), (7), (12), (17), (22), (27), (32), (37) and (42).

e. Neuroticism totalled eight statement items contained in numbers (4), (9), (14), (19), (24), (29), (34) and (39).

\section{Locus of Control}

Locus of control relates to how a person perceives the things that happen to them, in terms of whether they can control them or not (Rotter, 1966). This variable is measured using a 1-5 Likert scale based on an instrument used by Yendrawati and Witono (2011). This measurement is performed using one statement item.

\subsection{Data Analysis Technique}

Multiple regression was used as the data analysis technique in this study, with the data processed using Statistical Package for the Social Sciences (SPSS), which is a special application for processing statistical data

$$
\begin{aligned}
Y=\alpha+\beta_{1} \text { Conf } & +\beta_{2} \text { Size }+\beta_{3} \text { Open }+\beta_{4} \text { Cons }+\beta_{5} \text { Ext }+\beta_{6} \text { Agre }+\beta_{7} \text { Neur }+\beta_{8} \text { LInt } \\
& +\beta_{9} \text { LEks }+\beta_{10} \text { Conf }^{*} \text { Size }+\beta_{11} \text { Conf }{ }^{*} \text { Open }+\beta_{12} \text { Conf }^{*} \text { Cons } \\
& +\beta_{13} \text { Conf }{ }^{*} \text { Ext }+\beta_{14} \text { Conf }^{*} \text { Agre }+\beta_{15} \text { Conf }^{*} \text { Neur }+\beta_{16} \text { Conf }^{*} \text { LInt } \\
& +\beta_{17} \text { Conf }^{*} \text { LEks }+e
\end{aligned}
$$

\section{Information:}

$$
\begin{array}{ll}
\mathrm{Y} & =\text { auditor judgment bias } \\
\alpha & =\text { constants }
\end{array}
$$




$\begin{array}{ll}\beta_{1-17} & =\text { regression coefficient } \\ \text { Conf } & \text { role conflict } \\ \text { Size } & \text { = public accounting firm size } \\ \text { Open } & =\text { openness to experience } \\ \text { Cons } & =\text { conscientiousness } \\ \text { Ext } & =\text { extraversion } \\ \text { Agre } & =\text { agreeableness } \\ \text { Neur } & =\text { neuroticism } \\ \text { LInt } & =\text { internal locus of control } \\ \text { LEks } & =\text { external locus of control } \\ \text { Conf Size } & =\text { interaction of role conflict with public accounting firm size } \\ \text { Conf }{ }^{*} \text { Open } & =\text { interaction of role conflict with openness to experience } \\ \text { Conf Cons } & =\text { interaction of role conflict with conscientiousness } \\ \text { Conf Ext } & =\text { interaction of role conflict with extraversion } \\ \text { Conf }{ }^{*} \text { Agre } & =\text { interaction of role conflict with agreeableness } \\ \text { Conf Neur } & =\text { interaction of role conflict with neuroticism } \\ \text { Conf }{ }^{*} \text { LInt } & =\text { interaction of role conflict with internal locus of control } \\ \text { Conf }{ }^{*} \text { LEks } & =\text { interaction of role conflict with external locus of control } \\ \text { e } & =\text { error is the level of estimator error in the research. }\end{array}$

\section{RESULTS AND DISCUSSION}

This research used primary data that were collected through a questionnaire survey. A total of 84 questionnaires were collected from 24 public accounting firms. From the total collected, only 59 questionnaires from 19 public accounting firms were eligible to be processed.

The characteristics of the respondents in this research include gender, recent education, position and length of work. Based on gender, $52.5 \%$ of the respondents were female, with the remainder male. Almost all of the respondents, $98.3 \%$, had an education background of S1, with the remainder having S2. A total of $66.1 \%$ of the respondents held positions as junior auditors; $1-2.5$ years represented the majority for the length of work experience. Of the 59 respondents, 59.3\% were from non-Big Four public Aaccounting firms.

The results of the validity and reliability test in this research revealed that the instrument used was valid and reliable. An instrument can be said to be valid if it has a Pearson's correlation value > 0.25 . It is said to be reliable if it has a Cronbach's alpha $>0.60$.

Table 1: Validity and Reliability Testing

\begin{tabular}{lcc}
\hline \hline \multicolumn{1}{c}{ Variable } & Pearson Correlation & Cronbach's Alpha \\
\hline Auditor Judgment Bias & $0,300-0,649$ & 0,689 \\
Role Conflict & $0,457-0,775$ & 0,725 \\
Openness to Experience & $0,462-0,840$ & 0,841 \\
Conscientiousness & $0,576-0,805$ & 0,879 \\
Extraversion & $0,482-0,831$ & 0,851 \\
Agreeableness & $0,567-0,706$ & 0,809
\end{tabular}




\begin{tabular}{lcc}
\hline \hline \multicolumn{1}{c}{ Variable } & Pearson Correlation & Cronbach's Alpha \\
\hline Neuroticism & $0,531-0,841$ & 0,854 \\
Internal Locus of Control & $0,546-0,829$ & 0,832 \\
External Locus of Control & $0,650-0,875$ & 0,831 \\
\hline \hline
\end{tabular}

To avoid bias on the estimator value of the model used in this study, a classical assumption test was carried out first. The Kolmogorov-Smirnov test was conducted for normality and showed a significance value of $20 \%>5 \%$, thus indicating a normal residual spread and that the data was suitable for further testing. Heteroscedasticity was tested using Spearman's rank correlation coefficient and yielded a significance value for each variable greater than 0.5 , the table shows that the non-heteroscedasticity assumption was met.

Table 2: Hypothesis Testing

\begin{tabular}{|c|c|c|c|c|c|c|}
\hline Variable & $\beta$ & $\mathbf{t}$ & Sig. & $\begin{array}{l}\text { Predicted } \\
\text { Direction }\end{array}$ & Hypothesis & Conclusion \\
\hline Conf & 4,705 & 1,633 & 0,110 & Positive & $\mathrm{H}_{1}$ & Rejected \\
\hline Size & $-4,035$ & $-0,513$ & 0,611 & & & \\
\hline Open & 0,748 & 0,652 & 0,518 & & & \\
\hline Cons & $-2,042$ & $-1,389$ & 0,172 & & & \\
\hline Ext & 1,766 & 1,313 & 0,196 & & & \\
\hline Agre & 0,722 & 0,550 & 0,585 & & & \\
\hline Neur & 0,481 & 0,425 & 0,673 & & & \\
\hline LInt & 3,337 & 1,961 & 0,057 & & & \\
\hline LEks & $-1,044$ & $-1,339$ & 0,188 & & & \\
\hline Size*Conf & 0,195 & 0,539 & 0,593 & Positive & $\mathrm{H}_{2}$ & Rejected \\
\hline Open*Conf & $-0,011$ & $-0,216$ & 0,830 & Negative & $\mathrm{H}_{3 \mathrm{a}}$ & Rejected \\
\hline Cons*Conf & 0,098 & 1,400 & 0,169 & Negatif & $\mathrm{H}_{3 b}$ & Rejected \\
\hline Ext*Conf & $-0,098$ & $-1,526$ & 0,135 & Negative & $\mathrm{H}_{3 \mathrm{c}}$ & Rejected \\
\hline Agre*Conf & $-0,049$ & $-0,725$ & 0,473 & Positive & $\mathrm{H}_{3 \mathrm{~d}}$ & Rejected \\
\hline Neur*Conf & $-0,022$ & $-0,417$ & 0,679 & Positive & $\mathrm{H}_{3 \mathrm{e}}$ & Rejected \\
\hline LInt*Conf & $-0,176$ & $-2,141$ & 0,038 & Negative & $\mathrm{H}_{4 \mathrm{a}}$ & Accepted \\
\hline LEks*Conf & 0,052 & 1,309 & 0,198 & Positive & $\mathrm{H}_{4 \mathrm{~b}}$ & Rejected \\
\hline $\mathbf{R}$ & 0,644 & & & & & \\
\hline R Square & 0,414 & & & & & \\
\hline Adjusted $\mathbf{R}^{2}$ & 0,171 & & & & & \\
\hline
\end{tabular}

The result obtained was not predicted as only one hypothesis is accepted. However, it can be seen that individual factors do not affect professionalism in making audit judgements. The statistical test results displayed in Table 2 show that role conflict does not affect auditor judgement bias. Job demands require auditors to make judgements that are far from biased. This is because the judgements that they make are important not only for the companies being audited but also for the wider community that uses the financial statements for decision-making purposes. Thus, although 
in performing their duties, an auditor can face the problem of role conflict, they will continue to maintain their professionalism as an auditor, so that the judgements they make are not biased. The results of this research are in line with studies by Hanna and Firnanti (2013), Rahmiati and Kusuma (2004) and Viator (2001), which state that role conflict does not affect auditor performance.

The interaction between role conflict and public accounting firm size indicates that public accounting firm size does not moderate the relationship between role conflict and auditor judgement bias. As professional auditors, those working at both Big Four and non-Big Four firms will ensure that the judg they make are far from biased. Regardless of the degree of role conflict they face, they must maintain their professionalism as auditors. These results support Yaşar (2013) and Nindita and Siregar (2012), who found no difference in audit quality between Big Four and non-Big Four public accounting firms.

The interaction between the role conflict and personality variables in Table 5 shows that the personality traits (openness to experience, conscientiousness, extraversion, agreeableness and neuroticism) are not able to moderate the relationship between role conflict and auditor judgement bias. An auditor must be able to deal with and resolve any situation that occurs while performing the task and maintain their professionalism as an auditor. Therefore, different auditor personalities should not constitute a reason for producing a biased judgement, even if the auditor has to work in an unpleasant situation.

This research is in line with Rustiarini (2013a), which reported no influence of the personality traits of openness to experience and agreeableness on auditor performance. This research also accords with Rustiarini (2013b), which stated that the personality traits of extraversion and neuroticism do not play a role in the relationship between job stress and dysfunctional audit behaviour. Meanwhile, Robertson et al. (2000) stated that conscientiousness does not affect an individual's performance.

The result of the locus of control variable test indicates that the internal locus of control is able to moderate the relationship between role conflict and auditor judgement bias. Individuals with a high internal locus of control assume that everything they experience occurs as a result of their own actions and assume that a challenge can improve their performance. Therefore, auditors who have a high internal locus of control believe that their quality of judgement will depend on themselves. The results of this study are in line with Fatimah (2012) and Kartika and Wijayanti (2007), who found that an auditor's high internal locus of control will reduce their acceptance of dysfunctional behaviour. This research also supports Rustiarini (2013b), which states internal locus of control has a negative effect on the relationship between job stress and dysfunctional audit behavio.

Meanwhile, individuals with a high external locus of control assume that things that transpire in their life are either a gift from others or solely a matter of luck. However, this perception does not necessarily affect their professionalism as an auditor. Therefore, even if they perceive that everything that happens results from the influence of others, they do not directly accept others' requests if these are not in accordance with the principles they hold. Thus, external locus of control does not affect an auditor's judgement. The results of this study are in line with Iswari and Kusuma (2013), who found no effect of external locus of control on the relationship between organisationalprofessional conflict and professional judgement. 


\section{CONCLUSION}

Based on the test results obtained, the relationship between role conflict and auditor judgement bias is only moderated negatively by internal locus of control. Meanwhile, role conflict is not moderated by public accounting firm size, personality traits or external locus of control with respect to its influence on auditor judgement bias.

This study has several limitations. First, it only uses the Big Five personality traits to measure personality, dividing personality traits into the five dimensions of openness to experience, conscientiousness, extraversion, agreeableness and neuroticism. It is anticipated that future research will focus on other personal characteristics in order to further enrich the results of research related to personal characteristics in accounting. Secondly, this research only uses the questionnaire survey method and the researcher was unable to directly control the completion of the questionnaires. Further research is expected to combine data collection methods with interviews to ensure increased control is maintained over the data and greater clarification is obtained regarding the perception of respondents. This research only included made auditors working in public accounting firms in Java as its respondents, which means the results cannot be generalised to all auditors working in Indonesia. Further research is expected to expand the reach of the sample area so that the results have a higher level of generalisation.

\section{ACKNOWLEDGEMENT}

The author would like to thank the Accounting Programme of the Economics and Business Faculty of Universitas Muhammadiyah Yogyakarta for its continuous support and encouragement, and also extend sincere thanks to all of the respondents for their participation and cooperation

\section{REFERENCES}

Afifah, U., Sari, R. N., Anugerah, R., \& Sanusi, Z. M. (2015). The Effect of Role Conflict, SelfEfficacy, Professional Ethical Sensitivity on Auditor Performance with Emotional Quotient as Moderating Variable. Procedia Economics and Finance, 31, 206-212. https://doi.org/10.1016/S2212-5671(15)01222-8

Agustina, L. (2009). Pengaruh Konflik Peran, Ketidakjelasan Peran, dan Kelebihan Peran terhadap Kepuasan Kerja dan Kinerja Auditor. Jurnal Akuntansi, 1(1), 40-69.

Arens,A., Elder, R., \&Beasley, M. (2012), Auditing and Assurance Service. Prentice Hall.

Ayuningtyas, D. (2019). Gara-gara Lapkeu, Deretan KAP Ini Malah Kena Sanksi OJK. https://www.cnbcindonesia.com/market/20190809123549-17-90910/gara-gara-lapkeuderetan-kap-ini-malah-kena-sanksi-ojk

Barrick, M. R., \& Mount, M. K. (1991). The Big Five Personality Dimensions and Job Performance: A Meta-Analysis. Personnel Psychology, 44(1), 1-26.

Barrick, M. R., \& Mount, M. K. (2005). Yes , Personality Matters : Moving on to More Important Matters. Human Performance, 18(4), 359-372.

Bowling, N. A., \& Eschleman, K. J. (2010). Employee Personality as a Moderator of the Relationships Between Work Stressors and Counterproductive Work Behavior. Journal of Occupational Health Psychology, 15(1), 91-103. 
Denissen, J. J. A., \& Penke, L. (2008). Motivational individual reaction norms underlying the FiveFactor model of personality: First steps towards a theory-based conceptual framework. Jounal of Research in Personality, 42(5), 1285-1302.

Evanauli, R. P., \& Nazaruddin, I. (2016). Penerimaan Auditor atas Dysfungsional Audit Behavior: Sebuah Pendekatan Karakteristik Personal Auditor. Jurnal Akuntansi Dan Investasi, 14(2), 158-167.

Fanani, Z., Hanif, R. A., \& Subroto, B. (2008). Pengaruh Struktur Audit, Konflik Peran dan Ketidakjelasan Peran terhadap Kinerja Auditor. Jumal Akuntansi Dan Keuangan Indonesia, 5(2), 139-155.

Farhadi, H., Fatimah, O., Nasir, R., \& Shahrazad, W. (2012). Agreeableness and Conscientiousness as Antecedents of Deviant Behavior in Workplace. Asian Social Science, 8(9), 2-7.

Fatimah, A. (2012). Karakteristik Personal Auditor sebagai Anteseden Perilaku Disfungsional Auditor dan Pengaruhya terhadap Kualitas Hasil Audit. Jurnal Manajemen Dan Akuntansi, $1(1), 1-12$.

Fauzia, M. (2019). Pertumbuhan Ekonomi Papua dan Papua Barat Negatif di Kuartal II. https://money.kompas.com/read/2019/08/05/155532226/pertumbuhan-ekonomi-papua-danpapua-barat-negatif-di-kuartal-ii-2019

Fisher, R. T. (2001). Role Stress, the Type A Behaviour Pattern, and External Auditor Job Satisfaction and Performance. Behavioral Research in Accounting, 13, 143-170.

Goldberg, L. R. (1990). An Alternative "Description of Personality": The Big-Five Factor Structure. Journal of Personality and Social Psychology, 59(6), 1216-1229.

Graziano, W. G., \& Tobin, R. M. (2002). Agreeableness: Dimension of Personality or Social Desirability Artifact? Journal of Personality, 70(5), 695-728.

Hanna, E., \& Firnanti, F. (2013). Faktor-Faktor yang Memengaruhi Kinerja Auditor. Jurnal Bisnis Dan Akuntansi, 15(1), 1410-9875.

Harini, D., Wahyudin, A., \& Anisykurlillah, I. (2010). Analisis Penerimaan Auditor Atas Dysfunctional Audit Behavior: Sebuah Pendekatan Karakteristik Personal Auditor. Simposium Nasional Akuntansi XIII, 13, 1-28.

Iswari, T. I., \& Hardini, Y. (2017). The Moderating Effect of Public Accounting Firm Size on Correlation of Organizational- Professional Conflict and Auditor Judgment. Review of Integrative Business and Economics Research, 6(1), 427-436.

Iswari, T. I., \& Kusuma, I. (2013). The Effect of Organizational-Professional Conflict towards Professional Judgment by Public Accountant Using Personality Type, Gender, and Locus of Control as Moderating Variables. Review of Integrative Business and Economics Research, 2(22), 434-438.

Jamilah, S., Fanani, Z., \& Chandrarin, G. (2007). Pengaruh Gender, Tekanan Ketaatan dan Kompleksitas Tugas terhadap Audit Judgment. Simposium Nasional Akuntansi X. Retrieved from https://datakata.files.wordpress.com/2015/01/auep-06.pdf

Judge, T. A., Heller, D., \& Mount, M. K. (2002). Five-Factor Model of Personality and Job Satisfaction: A Meta-Analysis. Journal of Applied Psychology, 87(3), 530-541.

Kartika, I., \& Wijayanti, P. (2007, July 26-28). Locus of Control sebagai Anteseden Hubungan Kinerja Pegawai dan Penerimaan Perilaku Disfungsional Audit. Simposium Nasional $\begin{array}{llll}\text { Akuntansi } & X & \text { [Symposium]. Unhas Indonesia. }\end{array}$ https://datakata.files.wordpress.com/2015/01/auep-05.pdf

McCrae, R. R., \& Costa, P. T. (1987). Validation of the Five-Factor Model of Personality Across Instruments and Observers. Journal of Personality and Social Psychology, 52(1), 81-90.

Nindita, C., \& Siregar, S. V. (2012). Analisis Pengaruh Ukuran Kantor Akuntan Publik terhadap 
Kualitas Audit di Indonesia. Jurnal Akuntansi Dan Keuangan, 14(2), 91-104.

Noviyanti, S. (2008). Skeptisme Profesional Auditor dalam Mendeteksi Kecurangan. Jurnal Akuntansi Dan Keuangan Indonesia, 5(1), 102-125. https://doi.org/10.21002/jaki.2008.05

Rahmiati, \& Kusuma, I. W. (2004). Hubungan antara Mentoring dengan Role Stress dan Job Outcomes dalam Lingkungan Akuntan Publik. Simposium Nasional Akuntansi VII, 975-990. Ramdhani, N. (2007). Apakah Kepribadian Menentukan Pemilihan Media Komunikasi? Metaanalisis Terhadap Hubungan Kepribadian Extraversion, Neuroticism, dan Openness to Experience dengan Penggunaan Email. Jurnal Psikologi, 34(2), 112-129.

Robertson, I. T., Baron, H., Gibbons, P., Maclver, R., \& Nyfield, G. (2000). Conscientiousness and Managerial Performance. Journal of Occupational and Organizational Psychology, 73, 171180.

Rotter, B. J. (1966). Generalized Expectancies For Internal Versus External Control of Reinforcement. Psychological Monograph: General and applied, 80(1), 1-28.

Rustiarini, N. W. (2013a). Pengaruh Kompleksitas Tugas, Tekanan Waktu, dan Sifat Kepribadian pada Kinerja. Makara Seri Sosial Humaniora, 17(2), 126-138.

Rustiarini, N. W. (2013b). Sifat Kepribadian dan Locus of Control Sebagai Pemoderasi Hubungan

Stres Kerja dan Perilaku Disfungsional Audit. Simposium Nasional Akuntansi XVI. https://jurnals.com/wp-content/uploads/2013/11/sesi-2_split_11.pdf

Sawan, N., \& Alsaqqa, I. (2013). Audit firm size and quality: Does audit firm size influence audit quality in the Libyan oil industry? African Journal of Business Management, 7(3), 213-226.

Senatra, P. T. (1980). Role Conflict, Role Ambiguity, and Organizational Climate in a Public Accounting Firm. The Accounting Review, 55(4), 594-603.

Sorensen, J. E., \& Sorensen, T. L. (1974). The Conflict of Professionals in Bureaucratic Organizations. Administrative Science Quarterly, 19(1), 98-106.

Srimindarti, C., Sunarto, \& Widati, L. W. (2015). The Effects of Locus of Control and Organizational Commitment to Acceptance of Dysfunctional Audit Behavior Based on the Theory of Planned Behavior. International Journal of Business, Economics and Law, 7(1), 27-35.

Srirejeki, K. (2016). Pengaruh Keterlibatan Manager dan Evaluasi Kelompok terhadap Penilaian Strategi dengan Balanced Scorecard. Jurnal Akuntansi Dan Auditing Indonesia, 16(2), 122136.

Sugiyono. (2014). Metode Penelitian Bisnis. Bandung: Alfabeta.

Viator, R. E. (2001). The Association of Formal and Informal Public Accounting Mentoring with Role Stress and Related Job Outcomes. Accounting Organization and Society, 26, 73-93.

Wedemeyer, P. D. (2010). A Discussion of Auditor Judgment as the Critical Component in Audit Quality. International Journal of Disclosure and Governance, 7(4), 1741-3591.

Yaşar, A. (2013). Big Four Auditors' Audit Quality and Earnings Management: Evidence from Turkish Stock Market. International Journal of Business and Social Science, 4(17), 153-163.

Yendrawati, R., \& Witono. (2011). Pengaruh Sifat Machiavellian, Locus of Control dan Independensi terhadap Perilaku Etis Auditor (Studi Empiris pada Kantor Akuntan Publik di Yogyakarta). Jurnal Aplikasi Bisnis, 10(9), 1233-1256.

Yustrianthe, R. H. (2008). Pengaruh Flexible Work Arrangement terhadap Role Conflict, Role Overload, Reduced Personal Accomplishment, Job Satisfaction dan Intention to Stay. Jurnal Bisnis Dan Akuntansi, 10(3), 127-138. 